DOI https://doi.org/10.30929/2307-9770.2020.08.04.07

UDC 37.014.6:005.6:001.891 053.067

\title{
Effectiveness of using visualization in mathematics lessons
}

\author{
Skotnikova L. M.* \\ Kremenchuk Mykhailo Ostrohradskyi National University, Kremenchuk, Ukraine
}

Received: $12.06 .2020 \quad$ Accepted: 30.11 .2020

\begin{abstract}
The transformation of classical educational forms in the conditions of step-by-step implementing the Conceptual Principles "New Ukrainian School", in particular, through using educational material' visualization is researched. The purpose of the study is to analyze visualization as a methodological technique during mathematics lessons in secondary educational institutions. An empirical study of visualization as a methodological technique for lessons' effectiveness was carried out by means of an online questionnaire using Google forms service. The purpose of questionnaire was to determine frequency of visualization using in mathematics lessons, positive effects of visualization, as well as to clarify the problems associated with its use. Analysis of the results of the questionnaire indicates that this methodological technique is actively used in the educational activities of Poltava region secondary educational institutions teachers. Due to an analytical prioritization of the positive effects of visualization using in mathematics lessons it's showed that teachers note time saving and information saturation as the main benefits. Much less priority is given to such advantages as facilitating perception and memorization, as well as interactivity, which are of particular importance for senior students. It is concluded that such characteristics of respondents as the geography of educational institutions where survey participants work, as well as branches (mathematical knowledge groups), which include single parts of mathematics, were irrelevant in the aspect of using visualization as a methodological technique when conducting math lessons. The practical value of the study is due to the fact that its results can be used in lessons on other associated subjects related to didactics and methods of teaching mathematics. The results of monitoring the visualization in mathematics lessons at Poltava region secondary educational institutions can be used in further empirical studies on this field.
\end{abstract}

Keywords: mathematics lesson, visualization, methodology, multimedia and interactive technologies, secondary education, imaginative thinking.

\section{Ефективність використання візуалізації на уроках математики Скотнікова Л. М.}

Кременчуцький національний університет імені Михайла Остроградського, Кременчук, Україна

\begin{abstract}
Анотація. У статті розглянуто трансформацію класичних форм навчання в умовах поступового впровадження Концепції Нової української школи, зокрема, шляхом використання візуалізації навчального матеріалу. Мета дослідження полягає в аналізі візуалізації як методичного прийому під час проведення уроків математики у закладах загальної середньої освіти. За допомогою онлайн-анкетування з використанням сервісу Google forms було здійснено емпіричне дослідження візуалізації як методичного прийому, який підвищує ефективність уроків. Мета анкетування полягала у визначенні частоти застосування візуалізації на уроках математики, позитивних ефектів візуалізації, а також з'ясуванні проблем, пов'язаних з її використанням. Проаналізовано результати анкетування і виявлено, що даний методичний прийом активно застосовуеться в освітній діяльності учителів закладів загальної середньої освіти Полтавської області. Завдяки аналітичній пріоритизації позитивних ефектів використання візуалізації для проведення уроків математики показано, що як головні переваги учителі відзначають економію часу та інформаційну насиченість. Виявлено, що набагато менш пріоритетними вважаються такі переваги, як полегшення сприйняття і запам'ятовування, а також інтерактивність, що представляють особливе значення для учнів. Зроблено висновок про те, що нерелевантними в аспекті використання візуалізації як методичного прийому під час проведення уроків математики виявилися такі характеристики респондентів, як географія освітніх закладів, в яких працюють учасники анкетування, а також галузі (групи математичних знань), до яких належать окремі підрозділи
\end{abstract}

\footnotetext{
Corresponding Author: Skotnikova Ludmyla Mykolayivna. +38(05366)30050. E-mail: Iskotnikova7@gmail.com. Kremenchuk Mykhailo Ostrohradskyi National University,

Pershotravneva st, 20, Kremenchuk, Ukraine, 39600.

Відповідальний автор: Скотнікова Людмила Миколаївна. +38(05366)30050. E-mail: Iskotnikova7@gmail.com. Кременчуцький національний університет імені Михайла Остроградського, вул. Першотравнева, 20, м. Кременчук, Україна, 39600.
} 
математики. Практична цінність дослідження обумовлена тим, що його результати можуть бути використані в процесі проведення уроків з інших споріднених предметів, пов'язаних з дидактикою і методикою курсу математики. Результати моніторингу візуалізації під час проведення уроків математики в закладах загальної середньої освіти Полтавської області можуть використовуватися в подальших емпіричних дослідженнях 3 даної тематики.

Ключові слова: урок математики, візуалізація, методика, мультимедійні та інтерактивні технології, загальна середня освіта, образне мислення.

\title{
Эффективность использования визуализации на уроках математики
}

\section{Скотникова Л. М.}

Кременчугский национальный университет имени Михаила Остроградского, Кременчуг, Украина

\begin{abstract}
Аннотация. В статье рассмотрена трансформация классических форм обучения в условиях постепенного внедрения Концепции Новой украинской школы, в частности, путем использования визуализации учебного материала. Цель исследования заключается в анализе визуализации как методического приема при проведении уроков математики в учреждениях общего среднего образования. С помощью онлайнанкетирования с использованием сервиса Google forms было осуществлено эмпирическое исследование визуализации как методического приема, который повышает эффективность уроков. Цель анкетирования заключалась в определении частоты применения визуализации на уроках математики, положительных эффректов визуализации, а также выяснении проблем, связанных с ее использованием. Проанализированы результаты анкетирования и выявлено, что данный методический прием активно применяется в образовательной деятельности учителей учреждений общего среднего образования Полтавской области. Благодаря аналитической приоритизации положительных эффектов использования визуализации для проведения уроков математики показано, что в качестве главных преимуществ учителя отмечают экономию времени и информационную насыщенность. Выявлено, что гораздо менее приоритетными считаются такие преимущества, как облегчение восприятия и запоминания, а также интерактивность, представляющие особое значение для учащихся. Сделан вывод о том, что нерелевантными в аспекте использования визуализации как методического приема при проведении уроков математики оказались такие характеристики респондентов, как география образовательных учреждений, в которых работают участники анкетирования, а также отрасли (группы математических знаний), к которым относятся отдельные подразделы математики. Практическая ценность исследования обусловлена тем, что его результаты могут быть использованы в процессе проведения уроков по другим родственным предметам, связанным с дидактикой и методикой курса математики. Результаты мониторинга визуализации во время проведения уроков математики в учреждениях общего среднего образования Полтавской области могут использоваться в дальнейших эмпирических исследованиях по данной тематике.

Ключевые слова: урок математики, визуализация, методика, мультимедийные и интерактивные технологии, общее среднее образование, образное мышление.
\end{abstract}

\section{Bcmyn}

Нова українська школа в умовах швидкого розвитку глобального інформаційного суспільства потребує кардинального перегляду дидактичної парадигми. Перехід до розуміння результатів навчання як системи, що поєднує в собі як теоретичні знання, так і практичні навички, а також зміни, пов'язані 3 появою нового типу суб'єкта освіти - учня, який звик до сприйняття не текстової, а візуальної інформації - висувають перед загальною середньою освітою і сучасною дидактикою невідкладні завдання докорінного перегляду підходів, методик і прийомів навчання.

Відповідаючи на виклики часу, Нова українська школа реагує трансформацією класичних форм навчання. Це стосується й уроку як основної форми класно-урочної системи шкільного навчання. Класичний урок зазнає серйозних змін, переважно пов'язаних з тенденцією максимальної візуалізації навчальної інформації. Візуалізація, яка апелює до зорового сприйняття й образного мислення, що підключає окрім логіки й емоційну сферу, використовувалася в педагогіці завжди. Це могли бути яскраві образи, аналогії, ілюстрації до теоретичного матеріалу, що подаються в словесній фрормі, завдяки яким включалися уява і фантазія учнів. Цілі візуалізації переслідують і класичні навчальні підручники, демонстрація яких дозволяє учителеві урізноманітнити матеріал уроку. Проте сучасні реалії внесли корективи, і на сьогодні візуалізація освітнього процесу розуміється передусім як активне використання мультимедійного обладнання. 
Мультимедійні та інтерактивні уроки дозволяють учителеві говорити з учнем «однією мовою», оскільки покоління постмілленіалів, до якого належать сьогоднішні учні, що сформувалося в умовах діджиталізації і віртуалізації інформаційного поля, відрізняється здатністю ефективно працювати 3 інформацією, комунікувати і взаємодіяти за допомогою цифрових технологій. Представники цього покоління завдяки мережі Інтернет можуть миттєво отримати інформацію будь-якого обсягу за будьякою тематикою, тому вчитель перестав вважатися єдиним джерелом знань. Для сучасних учнів він $€$ скоріше медіатором, посередником, що дозволяє орієнтуватися в потоці інформації. Постмілленіалів відрізняють проблеми з довільною увагою і здатністю зосередитися, щоб вивчити певний матеріал. Їм необхідна постійна зміна діяльності. І, нарешті, для сучасних учнів «дізнатися» практично завжди тотожно «побачити». Для того щоб мотивувати їх на отримання знань, залучити до активної пізнавальної діяльності, необхідно подавати матеріал у доступній і цікавій для них фрормі. Саме такою формою і є урок з елементами візуалізації або урок-візуалізація, заснований на використанні сучасних цифрових (мультимедійних та інтерактивних) технологій.

Інноваційні педагогічні методики і прийоми організації уроків математики у закладах загальної середньої освіти посідають вагоме місце у роботах українських і зарубіжних дослідників-педагогів (А. Юрченко [1]; О. Рибалко [2]; K. Danielsson [3], [4], [5], [6]). Візуалізація розглядається в аспекті створення інноваційного освітнього середовища (Е. A. Makarova [7]; E. A. Makarova, E. L. Makarova i A. Varaks [8]; M. Nicholls [9]). Вчені досліджують дидактичний потенціал мультимедійних та інтерактивних занять (J. Moore [10]; A. Pavithra, M. Aathilingam i S. Murukanantha Prakash [11]), у тому числі, ефективність використання візуалізації на уроках математики (L. Navarro-Ibarra, A. García-Santillán, O. Cuevas-Salazar i J. Ansaldo-Leyva [12], A. Leung [13]). Візуалізація навчального матеріалу ділиться на певні типи за способом подачі інформації; так, виділяються статична і динамічна візуалізації (A. Arguel i E. Jamet [14]; B. Brucker, K. Scheiter i P. Gerjets [15]), flash-технології i java-аплети як окремий різновид візуалізації (Л. Огнівчук [16]). Також дослідники відзначають специфіку візуалізації в процесі вивчення предметів різних галузей знання: математики (J. Pettigrew i D. Shearman [17]), природничих наук (Y. Hu, L. Mazer i S. Yule [18]; D. Reinecke i L. Finn [19]), іноземних мов (J. Alivi i S. Suharyono [20]).

Особливо слід зазначити, що візуалізацію необхідно розглядати в аспекті змін сприйняття учнів. Пропонується враховувати специфріку нового покоління, що виросло в реаліях інфрормаційного суспільства. Сучасним учням властиво так зване «кліпове мислення» і складності в сприйнятті текстової інформації, у зв'язку з цим важливо не боротися з цим, а перебудувати освітній процес з урахуванням цієї особливості учнів.

Дослідники виокремлюють нові види навчальних моделей, що виникли під впливом прийому візуалізації. А. Юрченко [1] називає такі найпопулярніші візуальні форми подання навчальної інформації, що з'явилися на базі класичного уроку: модель у формі графа; продуктивна модель, логічна модель, фреймова модель, конспект-схема, карта пам'яті та ін. Дослідник зазначає, що «візуалізація навчальної інформації технологічно може бути реалізована різними методичними прийомами i, відповідно до цього, відомими різноманітними схемо-знаковими моделями представлення знань» [1].

Необхідною умовою для організації візуалізованого уроку $є$ електронні освітні ресурси. Варто зазначити, що в сучасній загальній середній освіті візуалізація навчального матеріалу здійснюється, зазвичай, за допомогою мультимедійних засобів.

Важливим ефектом уроку з елементами візуалізації $€$ когнітивні та емоційні зміни сприйняття. Варто звернути увагу на те, що включення мультимедійного та інтерактивного контенту дозволяє істотно підвищити якість сприйняття, оскільки подібний зміст є інформативнішим за рахунок підвищення психоемоційного сприйняття. Серед мультимедійних фрорм візуалізації можна виокремити веб-урок, слайд-урок, електронний комплекс предмету та ін. Ці нові типи впливають на структуру уроку та форми навчальної діяльності учнів, форми комунікації; на виникнення нових мережевих схем взаємодії вчителів і учнів та інших форм організації навчання.

Як показав огляд літератури, в умовах переходу до Нової української школи особливої актуальності в сучасній педагогіці набувають дослідження, спрямовані на модернізацію і вдосконалення освітнього процесу за допомогою візуалізації навчального матеріалу. Вивчення поточного стану і ключових тенденцій у сфері загальної середньої освіти свідчить про те, що на сьогодні стали очевидними істотні зміни, що стосуються змісту освіти, який стає все більш інформаційно насиченим, а 
також його методики, орієнтованої на використання можливостей сучасних інформаційно-комп'ютерних технологій. Дані трансформації пов'язані, передусім, з новим розумінням результатів освіти, які зараз формулюються в термінах компетенцій, а також зі зміною суб'єкта освіти (сучасні учні сфрормувалися в умовах нового інформаційного середовища, в якому переважає візуальна інформація), що передбачає серйозну корекцію методичного інструментарію, а саме, активного використання дидактичного потенціалу візуалізації. Без урахування цих змін неможливо організувати ефективний освітній процес.

Проте, окремі дослідники вказують на об'єктивні протиріччя в тому, яка форма організації уроку, що може підвищити мотивацію вивчення і пізнавальної діяльності, найцікавіша для учнів. Фахівці в галузі педагогіки загальної середньої освіти й інноваційних методів і засобів навчання в своїх роботах все частіше пропонують учителям переглянути традиційну класно-урочну фрорму на користь інтерактивних уроків з використанням сучасних інформаційних технологій [21]. Водночас, аналіз науковцями думки учнів говорить про те, що урок в будь-якій формі викликає інтерес, якщо він цікавий і досягає поставлені цілі - допомагає роз'ясненню і розв'язанню математичних завдань [22], [23].

Mema роботи: проаналізувати ефективність візуалізації як методичного прийому під час проведення уроків математики у закладах загальної середньої освіти.

Реалізація мети передбачає розв'язання низки завдань дослідження:

- проаналізувати поняття «візуалізація» у вітчизняній та зарубіжній педагогічній теорії;

- провести вибіркове групове онлайн-анкетування вчителів закладів загальної середньої освіти Полтавської області для з'ясування специфріки й ефективності використання візуалізації як методичного прийому організації уроків математики;

- на підставі результатів проведеного емпіричного дослідження (онлайн-анкетування) визначити місце і роль візуалізації в методичному інструментарії вчителів;

- здійснити аналітичну пріоритизацію позитивних ефектів використання візуалізації під час проведення уроків.

Об'єкт дослідження - візуалізація як методичний прийом організації уроків математики. Предмет дослідження - специфіка використання прийому візуалізації під час проведення уроків математики у закладах загальної середньої освіти Полтавської області.

\section{II Матеріал і методи дослідження}

Для розв'язання поставлених завдань і досягнення мети використано комплекс методів дослідження:

теоретичні - аналіз і синтез, індукція і дедукція, порівняння, аналогія, зіставлення - для з'ясування стану вивченості проблеми, визначення понятійно-категоріального апарату; узагальнення і систематизації наукових положень;

емпіричні-анкетування - для з'ясування специфіки використання візуалізації як методичного прийому організації уроків математики;

статистичні методи - для кількісного і якісного аналізу емпіричних даних за допомогою методів описової статистики (угрупування показників і побудова діаграм).

Такий комплексний підхід забезпечує проведення всебічного аналізу обраної теми.

Візуалізація найчастіше визначається педагогами-дослідниками як «процес згортання розумових змістів у наочний образ» [1]. Окремо науковці виокремлюють прийом просторової візуалізації, що являє собою «здатність когнітивно (розумово) перетворювати або маніпулювати візуальними просторовими властивостями об'єкта, що відрізняються від обертання об'єкта (тобто розумового обертання) або зміни перспективи (тобто просторової орієнтації), наприклад, візуалізація куба за допомогою його сітки або передбачення, як буде виглядати рисунок на розгорненому аркуші паперу» [24].

Використання методу візуалізації забезпечує образне уявлення знань і навчальних дій, тому у учнів виникає необхідність розпізнавання образів. Візуальна передача знань сприяє формуванню і розвитку візуального мислення і зорового сприйняття. Отже, візуальні методи представлення навчальної інформації, якщо не зводяться до простого ілюстрування, дозволяють забезпечити інтенсифікацію навчання та активізувати навчально-пізнавальну діяльність учнів.

Необхідно також зазначити, що навчання з елементами візуалізації створює необхідні дидактичні умови ефективної організації інтерактивних уроків математики, серед яких виділяються: підвищення 
рівня візуалізації навчального матеріалу за рахунок мультимедіа, когнітивної грасфіки та анімації; організація продуктивної групової навчальної діяльності на базі інтернет-ресурсів; здійснення зворотного зв'язку вчителя 3 класом, посилення самостійності, інформованості про результати навчання, оперативності контролю і самоконтролю за рахунок автоматизації атестаційних процедур; активізація рефлексії освітньої діяльності на основі проведення online-опитувань, форумів, чатів, коментування.

Емпіричне дослідження візуалізації як методичного прийому під час проведення уроків математики було здійснено шляхом вибіркового групового дистанційного онлайн-анкетування 3 використанням сервісу Google forms (https://www.google.com/int//ru ua/forms/about/). Такий різновид анкетування було обрано у зв'язку з його оперативністю і можливостями розширення вибірки (географії дослідження), тобто підвищення репрезентативності емпіричного дослідження. Мета анкетування полягала у визначенні частоти застосування візуалізації на уроках математики, позитивних ефектів візуалізації, а також у з'ясуванні проблем, пов'язаних з її використанням. 2020 року було опитано 114 респондентів, які є учителями закладів загальної середньої освіти м. Кременчук і Полтавської області. Географрія дослідження представлена 15 закладами, з яких чотири розташовані у Кременчуці (23 респонденти), два - в м. Горішні Плавні (18 респондентів), два - в Кременчуцькому районі (16 респондентів), три - в м. Полтава (22 респонденти), два - в м. Лубни (18 респондентів), два - в м. Хорол (17 респондентів).

В ході дослідження респонденти повинні були заповнити онлайн-анкету. Згідно з інструкцією учасникам анкетування пропонувалося відповісти на три питання: вказати, наскільки часто візуалізація як методичний прийом використовується ними під час проведення уроків математики (респондентам пропонувалося три варіанти відповіді - «постійно», «іноді» і «рідко»); вибрати із запропонованого списку позитивні ефекти візуалізації під час проведення уроків (учасникам надавалася також можливість додати власний варіант відповіді); а також самостійно назвати основні проблеми, пов'язані і використанням візуалізації у процесі викладення урочного матеріалу. Отже, анкета включала як закриті, так і відкриті питання. У складанні анкети використовувався принцип «від простого до складного» (складність питань нарощувалася поступово).

На початку анкети учасникам пропонувалося вказати місце роботи (місто, освітній заклад) і шкільні предмети, яким навчає респондент.

\section{III Результати}

Перше питання анкети стосувалося того, наскільки часто учасники (учителі закладів загальної середньої освіти) використовують методичний прийом візуалізації під час проведення уроків математики (рис. 1). Результати анкетування показали, що активно і регулярно використовують прийом візуалізації 59 респондентів $(51,8 \%)$, іноді використовують - 41 (35,9\%), рідко використовують $14(12,3 \%)$.

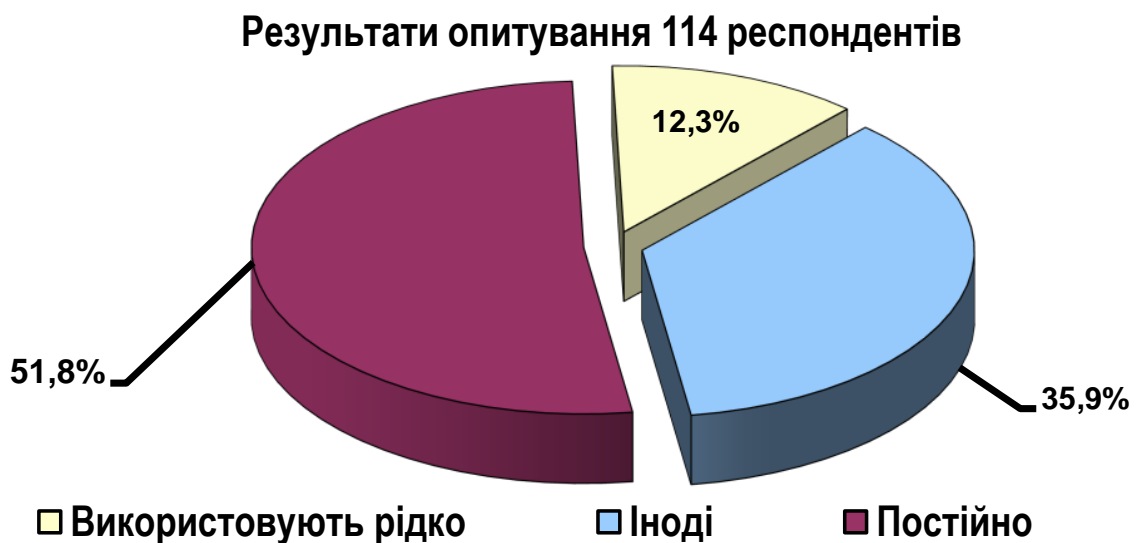

Рис. 1. Регулярність використання візуалізації під час проведення уроків математики 
Як показав аналіз емпіричних даних, візуалізація міцно увійшла в методичний арсенал сучасних учителів - переважна більшість респондентів регулярно (постійно або час від часу) користуються можливостями візуалізації під час проведення уроків. Завдяки глобалізації інфрормаційного суспільства візуалізація навчального матеріалу в освітньому процесі здійснюється учителями за допомогою мультимедійних та інтерактивних технологій, зокрема, використовується як статична візуалізація (слайд-шоу, електронні таблиці), так і динамічна (відеоматеріали, презентації).

Відповідь на друге запитання передбачала визначення позитивних ефектів візуалізації в організації уроків математики (учасникам надавалася також можливість додати власний варіант відповіді). Отримані в процесі опитування відповіді на питання щодо переваг візуалізації, завдяки яким респонденти покращують подачу математичної інформації на уроках, демонструють значну перевагу показників оперативності та якості інфрормації: економію часу як «плюс» візуалізації відзначили 60 респондентів (52,7 \%), інформаційну насиченість - 38 (33,3 \%), полегшення сприйняття і запам'ятовування - 8 (7\%), багатофункціональність - 6 (5,3\%), інтерактивність - 7 (2,3\%). Респондентам дозволялося вибрати не один, а кілька варіантів відповіді, тому загальний результат перевищує 100 \%. 3 самостійно доданих варіантів найчастіше називалася така перевага візуалізації, як емоційна привабливість - 4 (3,5 \%). Графічна інтерпретація результатів наведена на рис. 2.

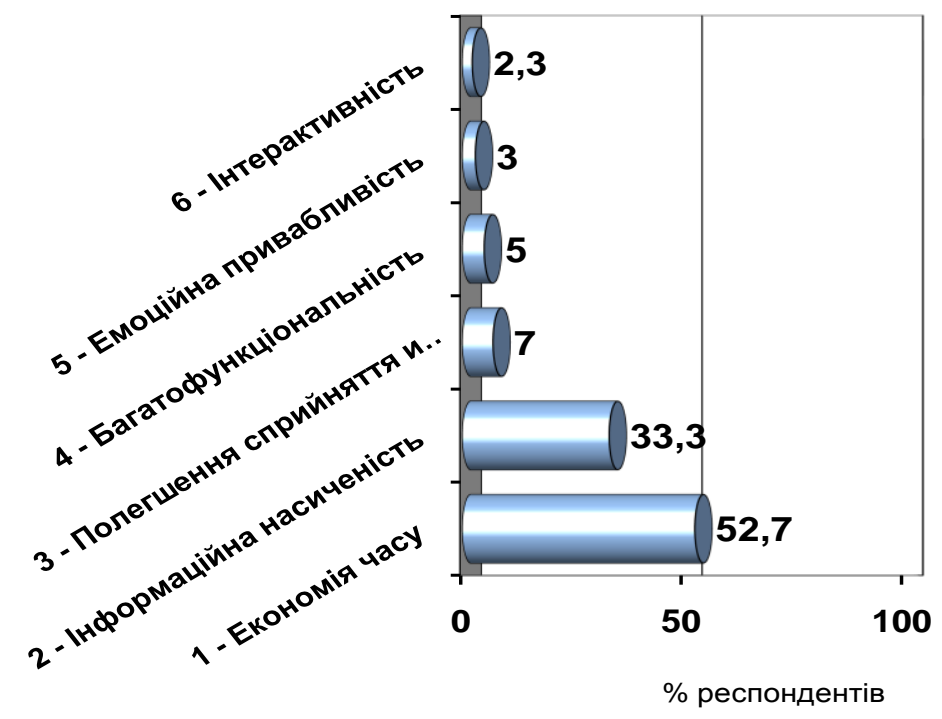

Рис. 2. Переваги («плюси») візуалізації під час проведення уроків математики

Аналіз результатів відповідей респондентів на дане питання викликає деяку тривогу в аспекті певного ухилення від принципів дитиноцентрованого підходу в навчанні, заснованого на особистісноорієнтованої моделі, запропонованої у Концепції Нової української школи. Економія часу і можливості максимального інформаційного ущільнення навчального матеріалу, які виділені як основні переваги візуалізації на уроках, важливі передусім для учителів; водночас, низькі показники мають такі позитивні ефекти візуалізації урочного матеріалу, як полегшення сприйняття і запам'ятовування, а також інтерактивність, особливо актуальні для учнів. Варто зазначити, що візуалізуючи матеріал уроку, учитель має прагнути до підвищення його доступності, легкості для розуміння і запам'ятовування, до розширення можливостей взаємодії, ефективності комунікації. Все це сприяє мотивації учнів в оволодінні ними математичними компетенціями (компетентісний підхід, закладений у Концепції Нової української школи), тобто досягненню програмних результатів вивчення математики.

У третьому пункті анкети респондентам пропонувалося самостійно назвати основні проблеми, пов'язані з використанням візуалізації під час проведення уроків математики. Учасники анкетування виявилися практично єдиними у тій думці, що основною проблемою $є$ недоліки матеріально-технічного забезпечення освітнього процесу, які ускладнюють використання мультимедійних та інтерактивних технологій в необхідному обсязі. Цю проблему назвали як головну й єдину 102 учасники анкетування $(89,5$ \%), інші респонденти не бачать проблем в організації уроків з використанням візуалізації. 
Дозволимо собі припустити, що випадки рідкісного використання візуалізації переважно пов'язані саме 3 даною проблемою. Гальмують впровадження педагогічних інновацій не відсталість і низька комп'ютерна компетентність учителів, а недостатні матеріально-технічні можливості освітніх закладів.

Нерелевантними в аспекті використання візуалізації як методичного прийому під час проведення уроків математики виявилися такі характеристики респондентів, як географрія освітніх закладів, в яких працюють учасники анкетування (табл. 1), а також галузі (групи математичних знань), до яких належать окремі підрозділи математики (табл. 2). Заявлені в анкетах респондентів курси були згруповані за чотирма групами математичних знань: алгебра, геометрія, планіметрія та стереометрія. Розбіжність показників із середніми значеннями не перевищує 3 \%, що дозволяє дійти висновку про те, що ситуація в різних закладах загальної середньої освіти і під час вивчення різних математичних тем є аналогічною.

Табл. 1: Частота використання методичного прийому візуалізації на уроках математики в закладах загальної середньої освіти різних районів Полтавської області

\begin{tabular}{|c|c|c|c|}
\hline \multirow{2}{*}{$\begin{array}{c}\text { Дислокація закладу } \\
\text { середньої освіти }\end{array}$} & \multicolumn{3}{|c|}{ Частота використання візуалізації (\%) } \\
\hline & Постійно & Іноді & Рідко \\
\hline м. Кременчук & 54,1 & 34,3 & 11,6 \\
\hline м. Горішні Плавні & 53,4 & 35,8 & 10,8 \\
\hline Кременчуцький район & 48,2 & 37,2 & 14,6 \\
\hline м. Полтава & 50,3 & 37,3 & 12,4 \\
\hline м. Лубни & 49,7 & 36,5 & 13,8 \\
\hline м. Хорол & 55,1 & 34,3 & 10,6 \\
\hline Середнє значення & 51,8 & 35,9 & 12,3 \\
\hline
\end{tabular}

Табл. 2: Частота використання методичного прийому візуалізації на уроках математики з різних галузей (груп математичних знань)

\begin{tabular}{|l|c|c|c|}
\hline \multirow{2}{*}{$\begin{array}{c}\text { Галузі } \\
\text { (групи математичних знань) }\end{array}$} & \multicolumn{3}{|c|}{ Частота використання візуалізації (\%) } \\
\cline { 2 - 4 } & Постійно & Іноді & Рідко \\
\hline Алгебра & 53,5 & 35,9 & 10,6 \\
\hline Геометрія & 50,2 & 36,3 & 13,5 \\
\hline Планіметрія & 51,9 & 35,1 & 13,0 \\
\hline Стереометрія & 51,6 & 36,3 & 12,1 \\
\hline \multicolumn{2}{|r}{} \\
\hline \multirow{2}{*}{ Середнє значення } & 51,8 & 35,9 & 12,3 \\
\hline
\end{tabular}

\section{IV Обговорення}

Думка про те, що традиційний урок математики має поступитися місцем урокам з використанням мультимедійних та інтерактивних технологій, є досить поширеною в сучасній науковій літературі. Тим цікавіше в цьому зв'язку емпіричне дослідження, проведене C. Hoyles, мета якого полягала в аналізі думки учнів і вчителів про те, якою має бути сучасна класно-урочна форма навчання математики. Дослідниця вказує на виявлене те, що візуалізація в ідеалі має лише доповнювати традиційну класноурочну форму занять, не витісняючи на периферію такі важливі її компоненти, як живе спонтанне спілкування і обмін думками між учасниками освітнього процесу [21].

Отже, варто погодитися з тим, що візуалізація уроків математики не повинна перетворюватися в самоціль. Мультимедійні та інтерактивні технології корисні і часто дозволяють «оживити» теорію, зробити матеріал уроку доступнішим, проте важливо пам'ятати, що неодмінна вимога щодо використання на уроках слайд-шоу або відеоматеріалів може привести до зниження якості комунікації між учителем і учнями, так само як і між самими учнями. Усне спонтанне спілкування на певну математичну тему, яке забезпечує класно-урочна форма занять, має бути збережено як основа. Візуалізація необхідна, але саме як один з багатьох методичних прийомів, тобто, вона має не бути тотальною. 
Поділяємо погляд дослідників T. Lowrie, T. Logan, D. Harris і M. Hegarty щодо тісної і постійної взаємодії понятійного і візуального мислення: «словесно-логічне мислення дає більш точне і узагальнене відображення дійсності, але це відображення абстрактно, а візуальне мислення допомагає сформувати образи і зробити їх цілісними і повними. Під час розробки навчально-методичних матеріалів учитель математики має постійно контролювати ступінь узагальнення змісту навчання, а під час проведення уроків дублювати вербальну інформацію образною і навпаки» [24]. Такий баланс між словесною і образною інформацією, на наш погляд, $є$ запорукою гармонійного розвитку майбутнього фахівця, створення міцної бази для досягнення програмних результатів освіти.

K. Danielsson зазначає, що уміння успішно оперувати одночасно текстовою і образною інформацією створює передумови для формування так званих «soft skills» або гнучких навичок, необхідних для успішної адаптації випускника закладів середньої освіти в сучасних умовах. Відеоматеріали та презентації корисні і зручні для демонстрації прикладів і систематизації інформації, проте живе спілкування в системі «учитель - учні» не менш важливо і потрібно для вироблення цих надпрофесійних умінь. Урок має враховувати однаково важливу роль різних семіотичних ресурсів у передачі знань [3]. У зв'язку з цим слушною вважаємо думку S. Mukherjee, який вказує на те, що для успішного використання методичного прийому візуалізації важливий ретельний підбір освітніх матеріалів. Мультимедіа продукти та онлайн-послуги мають бути обрані відповідно до загальних цілей освітньої діяльності. Необхідно враховувати рівень знань і навичок учнів, специфріку конкретної навчальної програми. Все це дозволяє досятти ефективності в процесі отримання знань 3 використанням візуалізації [25]. Важливим фрактором, на наш погляд, є також досвід, кваліфікація і медіаграмотність вчителя, що має значення під час вибору і систематизації візуальних матеріалів. У зв'язку з тим, що в сучасному освітньому процесі учителеві доводиться конкурувати за увагу учнів 3 різними джерелами інформації, роль візуальної грамотності важко переоцінити.

Різні способи візуалізації навчального матеріалу особливо наочно можна продемонструвати в ході проведення уроку з використанням презентації, під якою ми розуміємо класичний урок, підкріплений візуальним образно-інформаційним матеріалом, створеним за допомогою спеціального програмного забезпечення (наприклад, програми MS PowerPoint або редактора PDF-файлів) i демонстрованим за допомогою LCD-проектора на екран.

На значенні візуалізації навчальної інформації наполягають В. Brucker, K. Scheiter i P. Gerjets [15], K. Kuosa, D. Distante, A. Tervakari, L. Cerulo, A. Fernandez, J. Koro і M. Kailanto [26], особливості реалізації принципу наочності в процесі організації уроку-візуалізації підкреслюють А. Юрченко [1], використання технічних засобів візуалізації у вивченні математики розглядають L. Navarro-lbarra, A. García-Santillán, O. Cuevas-Salazar i J. Ansaldo-Leyva [12], J. Pettigrew i D. Shearman [17].

Погоджуємося з О. Рибалко, що використання інтерактивних електронних таблиць на уроках математики забезпечує наочність, яка сприяє кращому запам'ятовуванню та комплексному сприйняттю навчального матеріалу, особливо учнями початкових класів [2]. D. Reinecke i L. Finn зазначають, що відео-уроки дозволяють полегшити показ графіків, таблиць, рисунків, при цьому матеріал уроку сприймається на рівні відчуттів, підкріплюється зоровими образами» [19]. Проте, дещо дискусійною вважаємо тезу дослідників про те, що «інфрормація, представлена в презентації, у учнів закріплюється підсвідомо на рівні інтуїції» [19]. Вважаємо за необхідне відзначити, що будь-який урок, в тому числі 3 використанням презентацій, електронних таблиць і відеоматеріалів, апелює головним чином до свідомості учнів, хоча за умови використання візуалізації в дещо більшій мірі задіюється емоційна сфрера. Отже, візуалізація розглядається вченими як спосіб модернізації, підвищення переконливості класичного уроку, тобто як методичний прийом, спрямований на посилення його дидактичного ефекту.

\section{V Висновки}

Візуалізація належить до ефективних методичних прийомів, що дозволяють включати в роботу одночасно понятійне і образне мислення, унаслідок чого підвищується рівень засвоєння матеріалу уроку математики, зростають інтерес і мотивація учнів. В умовах переходу до Нової української школи візуалізація навчальної інформації має бути неодмінним атрибутом сучасної загальної середньої освіти.

Результати аналізу проведеного вибіркового групового онлайн-анкетування учителів закладів загальної середньої освіти Полтавської області для з'ясування специфіки використання візуалізації 
вказують на те, що даний методичний прийом активно застосовується в освітній діяльності українських учителів.

Аналітична пріоритизація позитивних ефректів використання візуалізації під час проведення уроків математики показала, що як головні переваги візуалізації учителі відзначають економію часу та інформаційну насиченість подібних уроків. Водночас, набагато менш пріоритетними з погляду учителів вважаються такі показники, як полегшення сприйняття і запам'ятовування, а також інтерактивність, що мають особливе значення для учнів. Такі характеристики респондентів, як географія закладів освіти, у яких працюють учасники анкетування та галузі (групи математичних знань), до яких належать окремі підрозділи математики, виявилися нерелевантними в аспекті використання візуалізації як методичного прийому під час проведення уроків математики.

Практична цінність дослідження зумовлена тим, що його результати можуть бути використані в процесі вивчення споріднених предметів, пов'язаних з дидактикою і методикою курсу математики. Результати моніторингу візуалізації під час проведення уроків математики в закладах загальної середньої освіти різних районів Полтавської області можуть стати підставою для подальших емпіричних досліджень з даної тематики. Так, перспективним вважаємо вивчення думки учнів щодо переваг візуалізації матеріалу уроків математики та проблем, пов'язаних з використанням цього методичного прийому.

\section{Бібліограффічні посилання}

1. Юрченко А. О. Особливості когнітивно-візуального підходу під час візуалізації навчального матеріалу з математики. Інноваційна педагогіка. 2019. Т. 3, Вип. 11. С. 62-67.

2. Рибалко О. О. Створення та застосування інтерактивних електронних таблиць на уроках математики в початкових класах. Інформаційні технології і засоби навчання. 2016. Т. 53, Вип. 3. С. 38-48. DOI: https://doi.org/10.33407/itt.v53i3.1373

3. Danielsson K. Modes and meaning in the classroom - The role of different semiotic resources to convey meaning in science classrooms. Linguistics and Education. 2016. Vol. 35, P. 88-99. DOI: https://doi.org/10.1016/.linged.2016.07.005

4. Weinberg A., McMeeking L. Toward Meaningful Interdisciplinary Education: High School Teachers' Views of Mathematics and Science Integration. School Science and Mathematics. 2017. Vol. 117, Iss. 5. P. 204-213. DOI: https://doi.org/10.1111/ssm.12224

5. Ling Koh J.H. Articulating Teachers' Creation of Technological Pedagogical Mathematical Knowledge (TPMK) for Supporting Mathematical Inquiry with Authentic Problems. Intermational Journal of Science and Mathematics Education. 2019. Vol. 17, Iss. 6. P. 1195-1212. DOl: https://doi.org/10.1007/s10763-018-9914-y

6. Sinicrope R., Eppler M., Preston R., Ironsmith M. Preservice Teachers of High School Mathematics: Success, Failure, and Persistence in the Face of Mathematical Challenges. School Science and Mathematics. 2015. Vol. 115, Iss. 2. P. 56-65. DOI: https://doi.org/10.1111/ssm.12104

7. Makarova E. A. Visual Culture in Educational Environment and Innovative Teaching Technologies. Universal Journal of Management. 2016. Vol. 4, Iss. 11. P. 621-627. DOI: https://doi.org/10.13189/ujm.2016.041104

8. Makarova E. A., Makarova E. L., Varaks A. M. Education process visualization in metacognition development and sustainability. International Journal of Cognitive Research in Science, Engineering and Education. 2017. Vol. 5, Iss. 2. P. 65-74. DOI: https://doi.org/10.5937/IJCRSEE1702065A

9. Nicholls M. Digital Visualisation in Classics Teaching and Beyond. Journal of Classics Teaching. 2016. Vol. 17, Iss. 33. P. 27-30. DOI: https://doi.org/10.1017/S2058631016000076

10. Moore J. C. Efficacy of Multimedia Learning Modules as Preparation for Lecture-Based Tutorials in Electromagnetism. Education Sciences. 2018. Vol. 8, Iss. 23. P. 1-14. DOI: https://doi.org/10.3390/educsci8010023

11. Pavithra A., Aathilingam M. and Murukanantha Prakash S. Multimedia and its applications. International journal for research \& development in technology. 2018. Vol. 10, Iss. 5. P. 271-276.

12. Navarro-Ibarra L., García-Santillán A., Cuevas-Salazar O., Ansaldo-Leyva J. Mathematics, Technology and Learning: How to Align These Variables in Order to Explain Anxiety Towards Mathematics and Attitude Towards the Use of Technology for Learning Mathematics. EURASIA Journal of Mathematics Science and Technology Education. 2017. Vol. 13, Iss. 9. P. 62116229. DOI: https://doi.org/10.12973/eurasia.2017.01060a

13. Leung A. Exploring STEM Pedagogy in the Mathematics Classroom: a Tool-Based Experiment Lesson on Estimation. International Journal of Science and Mathematics Education. 2019. Vol. 17, Iss. 7. P. 1339-1358. DOI: https://doi.org/10.1007/s10763-018-9924-9

14. Arguel A., Jamet E. Using video and static pictures to improve learning of procedural contents. Computers in Human Behavior. 2009. Vol. 25, Iss. 2. P. 354-359.

15. Brucker B., Scheiter K., Gerjets P. Learning with dynamic and static visualizations: Realistic details only benefit learners with high visuospatial abilities. Computers in Human Behavior. 2014. Vol. 36. P. 330-339. 
16. Огнівчук Л.М. Використання flash-технологій і јаvа-аплетів в електронному навчальному курсі 3 елементарної математики. Інформаційні технології i засоби навчання. 2015. Т. 4, Вип. 48. URL: http://journal.iitta.gov.ua/index.php/ittl/article/view/1249.

17. Pettigrew J., Shearman D. Developing interactive mathematical visualizations. Proceedings of ASCILITE 2014 - Annual Conference of the Australian Society for Computers in Tertiary Education. 2014. P. 539-543.

18. Hu Y.Y., Mazer L.M., Yule S.J. Complementing Operating Room Teaching With Video-Based Coaching. Jama surgery. 2017. Vol. 152, Iss. 4. P. 318-325.

19. Reinecke D., Finn L. Video lectures in online graduate education: Relationship between use of lectures and outcome measures. Journal of Information Technology Education: Research. 2015. Vol. 14. P. 73-90.

20. Alivi J.S., Suharyono S. Obtaining listening comprehension by using video materials. Jurnal Pendidikan Bahasa Inggris. 2016. Vol. 5, Iss. 1. P. 56-72.

21. Hoyles C. Transforming the mathematical practices of learners and teachers through digital technology. Research in Mathematics Education. 2018. Vol. 20, Iss. 3. P. 209-228. DOI: https://doi.org/10.1080/14794802.2018.1484799

22. Bicer A., Capraro R. Mathematics achievement in the secondary high school context of STEM and non-STEM schools. School Science and Mathematics. 2019. Vol. 119, Iss. 2. P. 61-71. DOl: https://doi.org/10.1111/ssm.12321

23. Mohd Rustam R., Azlina K. Challenges in mathematics learning: a study from school students' perspective. URL: https://www.researchgate.net/publication/321873178_Challenges_in_Mathematics_Learning_A_Study_from_School_Student's Perspective. (дата звернення: 11.09.2020).

24. Lowrie T., Logan T., Harris D., Hegarty M. The impact of an intervention program on students' spatial reasoning: student engagement through mathematics-enhanced learning activities. Cognitive Research: Principles and Implications. 2018. Vol. 3, Iss. 50. P. 56-65. DOI: https://doi.org/10.1186/s41235-018-0147-y

25. Mukherjee S. Role of multimedia in education. Edelweiss Applied Science and Technology. 2018. Vol. 2, Iss. 1. P. $245-247$.

26. Kuosa K., Distante D., Tervakari A., Cerulo L., Fernandez A., Koro J., Kailanto M. Interactive Visualization Tools to Improve Learning and Teaching in Online Learning Environments. International Journal of Distance Education Technologies. 2016. Vol. 14. P. 1-21.

\section{References}

1. Yurchenko A. O. Osoblyvosti kohnityvno-vizual'noho pidkhodu pid chas vizualizatsiyi navchal'noho materialu z matematyky. Innovatsiyna pedahohika. 2019. T. 3, Vyp. 11. S. 62-67.

2. Rybalko O. O. Stvorennya ta zastosuvannya interaktyvnykh elektronnykh tablyts' na urokakh matematyky v pochatkovykh klasakh. Informatsiyni tekhnolohiyi i zasoby navchannya. 2016. T. 53, Vyp. 3. S. 38-48. DOI: https://doi.org/10.33407/ittt.v53i3.1373

3. Danielsson K. Modes and meaning in the classroom - The role of different semiotic resources to convey meaning in science classrooms. Linguistics and Education. 2016. Vol. 35, P. 88-99. DOI: https://doi.org/10.1016/j.linged.2016.07.005

4. Weinberg A., McMeeking L. Toward Meaningful Interdisciplinary Education: High School Teachers' Views of Mathematics and Science Integration. School Science and Mathematics. 2017. Vol. 117, Iss. 5. P. 204-213. DOI: https://doi.org/10.1111/ssm.12224

5. Ling Koh J. H. Articulating Teachers' Creation of Technological Pedagogical Mathematical Knowledge (TPMK) for Supporting Mathematical Inquiry with Authentic Problems. International Journal of Science and Mathematics Education. 2019. Vol. 17, Iss. 6. P. 1195-1212. DOI: https://doi.org/10.1007/s10763-018-9914-y

6. Sinicrope R., Eppler M., Preston R., Ironsmith M. Preservice Teachers of High School Mathematics: Success, Failure, and Persistence in the Face of Mathematical Challenges. School Science and Mathematics. 2015. Vol. 115, Iss. 2. P. 56-65. DOI: https://doi.org/10.1111/ssm.12104

7. Makarova E. A. Visual Culture in Educational Environment and Innovative Teaching Technologies. Universal Journal of Management. 2016. Vol. 4, Iss. 11. P. 621-627. DOI: https://doi.org/10.13189/ujm.2016.041104

8. Makarova E. A., Makarova E. L., Varaks A. M. Education process visualization in metacognition development and sustainability. International Journal of Cognitive Research in Science, Engineering and Education. 2017. Vol. 5, Iss. 2. P. 65-74. DOI: https://doi.org/10.5937//JCRSEE1702065A

9. Nicholls M. Digital Visualisation in Classics Teaching and Beyond. Journal of Classics Teaching. 2016. Vol. 17, Iss. 33. P. 27-30. DOI: https://doi.org/10.1017/S2058631016000076

10. Moore J. C. Efficacy of Multimedia Learning Modules as Preparation for Lecture-Based Tutorials in Electromagnetism. Education Sciences. 2018. Vol. 8, Iss. 23. P. 1-14. DOI: https://doi.org/10.3390/educsci8010023

11. Pavithra A., Aathilingam M. and Murukanantha Prakash S. Multimedia and its applications. International journal for research \& development in technology. 2018. Vol. 10, Iss. 5. P. 271-276.

12. Navarro-Ibarra L., García-Santillán A., Cuevas-Salazar O., Ansaldo-Leyva J. Mathematics, Technology and Learning: How to Align These Variables in Order to Explain Anxiety Towards Mathematics and Attitude Towards the Use of Technology for Learning Mathematics. EURASIA Journal of Mathematics Science and Technology Education. 2017. Vol. 13, Iss. 9. P. 62116229. DOI: https://doi.org/10.12973/eurasia.2017.01060a

13. Leung A. Exploring STEM Pedagogy in the Mathematics Classroom: a Tool-Based Experiment Lesson on Estimation. International Journal of Science and Mathematics Education. 2019. Vol. 17, Iss. 7. P. 1339-1358. DOI: https://doi.org/10.1007/s10763-018-9924-9 
14. Arguel A., Jamet E. Using video and static pictures to improve learning of procedural contents. Computers in Human Behavior. 2009. Vol. 25, Iss. 2. P. 354-359.

15. Brucker B., Scheiter K., Gerjets P. Learning with dynamic and static visualizations: Realistic details only benefit learners with high visuospatial abilities. Computers in Human Behavior. 2014. Vol. 36. P. 330-339.

16. Ohnivchuk L.M. Vykorystannya flash-tekhnolohiy i java-apletiv $v$ elektronnomu navchal'nomu kursi $z$ elementarnoyi matematyky. Informatsiyni tekhnolohiyi i zasoby navchannya. 2015. T. 4, Vyp. 48. URL: http://journal.iitta.gov.ua/index.php/itt/article/view/1249.

17. Pettigrew J., Shearman D. Developing interactive mathematical visualizations. Proceedings of ASCILITE 2014 - Annual Conference of the Australian Society for Computers in Tertiary Education. 2014. P. 539-543.

18. Hu Y.Y., Mazer L.M., Yule S.J. Complementing Operating Room Teaching With Video-Based Coaching. Jama surgery. 2017. Vol. 152, Iss. 4. P. 318-325.

19. Reinecke D., Finn L. Video lectures in online graduate education: Relationship between use of lectures and outcome measures. Journal of Information Technology Education: Research. 2015. Vol. 14. P. 73-90.

20. Alivi J.S., Suharyono S. Obtaining listening comprehension by using video materials. Jurnal Pendidikan Bahasa Inggris. 2016. Vol. 5, Iss. 1. P. 56-72.

21. Hoyles C. Transforming the mathematical practices of learners and teachers through digital technology. Research in Mathematics Education. 2018. Vol. 20, Iss. 3. P. 209-228. DOI: https://doi.org/10.1080/14794802.2018.1484799

22. Bicer A., Capraro R. Mathematics achievement in the secondary high school context of STEM and non-STEM schools. School Science and Mathematics. 2019. Vol. 119, Iss. 2. P. 61-71. DOI: https://doi.org/10.1111/ssm.12321

23. Mohd Rustam R., Azlina K. Challenges in mathematics learning: a study from school students' perspective. URL: https://www.researchgate.net/publication/321873178_Challenges_in_Mathematics_Learning_A_Study_from_School_Student's Perspective. (дата звернення: 11.09.2020).

24. Lowrie T., Logan T., Harris D., Hegarty M. The impact of an intervention program on students' spatial reasoning: student engagement through mathematics-enhanced learning activities. Cognitive Research: Principles and Implications. 2018. Vol. 3, Iss. 50. P. 56-65. DOI: https://doi.org/10.1186/s41235-018-0147-y

25. Mukherjee S. Role of multimedia in education. Edelweiss Applied Science and Technology. 2018. Vol. 2, Iss. 1. P. 245-247.

26. Kuosa K., Distante D., Tervakari A., Cerulo L., Fernandez A., Koro J., Kailanto M. Interactive Visualization Tools to Improve Learning and Teaching in Online Learning Environments. International Journal of Distance Education Technologies. 2016. Vol. 14. P. 1-21.

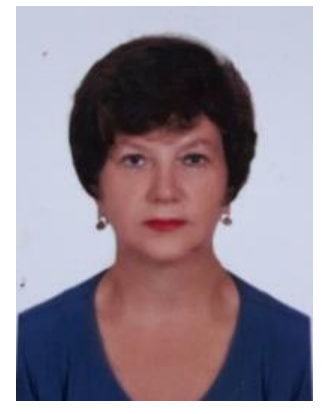

Скотнікова Людмила Миколаївна,

Старший викладач кафедри інформатики і вищої математики,

Кременчуцький національний університет імені Михайла Остроградського,

адреса. вул. Першотравнева, 20, м. Кременчук, Україна, 39600

Тел. (05366) 3-00-50. E-mail: Iskotnikova7@gmail.com

\section{Skotnikova Ludmyla Mykolayivna,}

Senior lecturer of Mathematics and Computer Science Department

Kremenchuk Mykhailo Ostrohradskyi National University,

Pershotravneva st, 20, Kremenchuk, Ukraine, 39600

Tel. +38(05366) 30050. E-mail: Iskotnikova7@gmail.com

ORCID: 0000-0001-6470-3280

Citation (APA):

Skotnikova L. M. (2020). Effectiveness of using visualization in mathematics lessons. Engineering and Educational Technologies, 8 (4), 74-84. doi: https://doi.org/10.30929/2307-9770.2020.08.04.07

\section{Цитування (ДСТУ 8302:2015):}

Скотнікова Л. М. Ефективність використання візуалізації на уроках математики / Інженерні та освітні технології. 2020. Т. 8. № 4. C. 74-84. doi: https://doi.org/10.30929/2307-9770.2020.08.04.07

Обсяг статmі: сторінок-11; умовних друк. аркушів - 1,593. 